\begin{tabular}{|c|c|c|}
\hline & Journal Homepage: - www.journalijar.com & $\begin{array}{l}\text { INTERNATIONAL JOURNAL OF } \\
\text { ADVANCED RESEARCH (IJARJ }\end{array}$ \\
\hline อ. $2320-5407$ & $\begin{array}{l}\text { Article DOI: } 10.21474 / \text { IJAR01/8202 } \\
\text { DOI URL: http://dx.doi.org/10.21474/IJAR01/8202 }\end{array}$ & \\
\hline
\end{tabular}

RESEARCH ARTICLE

\title{
HAEMORRHAGIC CONTUSIONS OF BRAIN : PREDICTORS OF OUTCOME AND RELATIONSHIP BETWEEN CLINICAL AND RADIOLOGICAL EVOLUTION.
}

Balamurugan S, Anil Kumar J and Indunesh K

Coimbatore Medical College and Hospital, Department of Neurosurgery, CMCH, Coimbatore 18.

\section{Manuscript Info}

\section{Manuscript History}

Received: 12 October 2018

Final Accepted: 14 November 2018

Published: December 2018

\section{Keywords:}

Traumatic brain injury ( TBI ), brain contusion, progression of contusion, clinical and radiological outcome.

\section{Abstract}

The most common sequelae of traumatic brain injuries (TBIs) are traumatic parenchymal mass lesions, accounts $\sim 13 \%$ of all TBI cases and $13 \%-35 \%$ of severe TBI cases, and for up to $20 \%$ of surgical intracranial lesions. The relationship between clinical and radiological evolution of haemorrhagic progression of brain contusions do exists with controversies.

Aim:To identify predictors of unfavourable outcome, analyse haemorrhagic progression brain contusions and evaluate specific indications for surgery.

Methods:A retrospective study, in which patients with brain contusions were identified in separate patient cohorts from Coimbatore medical college hospital, over a period of 1 year ( August 2017 - July 2018). Clinical data \& its parameters and course of the contusion were collected. Radiological parameters were registered using CT images during hospital admission and at subsequent follow-up. Patients who underwent surgical procedures were identified. Glasgow Outcome Scale-Extended used to evaluate the outcome 6 months after trauma.

Results:Multivariate analysis revealed the following reliable predictors of unfavourable outcome: 1) increased patient age, 2) lower Glasgow Coma Scale score at first evaluation, 3) clinical deterioration in the first hours after trauma, and 4) onset or increase of midline shift on followup CT images. Further multivariate analysis identified the following as statistically significant predictors of clinical deterioration during the first hours after trauma: 1) onset of or increase in midline shift on follow-up CT images ( $p<0.001)$ and 2) increased effacement of basal cisterns on follow-up CT images $(\mathrm{p}<0.001)$.

Conclusion :The onset of clinical deterioration is associated with the onset or increase of midline shift and worsened status of basal cisterns but not with increase in hematoma or oedema volume. The most reasonable indicator of surgery is the combination of clinical deterioration and increased midline shift/basal cistern compression.

Copy Right, IJAR, 2018,. All rights reserved.

\section{Corresponding Author:-Balamurugan S}

Address:-Coimbatore medical college and hospital, department of neurosurgery, cmch, coimbatore 18. 


\section{Introduction:-}

Throughout the world, traumatic brain injury (TBI) remains a significant cause of neurological morbidity and mortality. TBI is the most disabling of traumatic injuries, often leading to lifelong physical, cognitive, behavioural, and emotional impairment. ${ }^{1,2,11}$ The most common mass lesions associated with TBI are hematomas and contusions, which occur in $13 \%-35 \%$ of patients following TBI. ${ }^{2,5}$

Among comatose patients, even though the frequency of post-traumatic mass lesions is higher, these lesions also occur in patients with mild or moderate head injury. Majority of these patients will recover without deleterious sequelae, but a few will progressively deteriorate, even to death (talk-and-die cases). ${ }^{16}$ Follow up imaging of cerebral contusions typically shows a progressive increase in mass lesions. ${ }^{4,6,14,15,20}$. This change can be a result of hematoma expansion, appearance of peri-hematoma edema, or even of the development of new lesions in previously uninjured brain areas. ${ }^{17,20}$

The term " radiological evolution" has a scientific literature that lacks uniformity in defining it and due to different clinical studies which has reported haemorrhagic contusion progression ( $16.4 \%$ to $51 \%$ ), clinical definition stands controversial. ${ }^{1,2,4,6,14,15,21,24}$.

A classification of head injury based on CT Brain imaging proposed by Marshall et al. ${ }^{12}$ They stratified head injury according to the status of the mesencephalic cisterns, the presence of midline shift (>5 mm), and the volume of the main intracranial lesion (> $25 \mathrm{ml}$ ). According to a recent review by the Brain Trauma Foundation, ${ }^{2}$ current clinical indications for surgery for traumatic brain contusions comprise an amalgam of clinical and radiographic criteria, including lower Glasgow Coma Scale (GCS) score, presence of neurological deterioration, location of contusion, increased lesion volume, CT image appearance (increased midline shift and/or basal cistern compression), and increased intracranial pressure (ICP). Among these parameters, the most frequent factors used by attending neurosurgeons as criteria for surgical intervention for posttraumatic parenchymal damage are radiological and clinical deterioration. ${ }^{17}$ The aim of the present study was to evaluate which factors best predicted clinical and radiological progression and the need for surgical intervention and outcome in patients who underwent conservative management for brain contusions.

\section{Methods:-}

A retrospective study from a prospectively registered database in which the records of all patients with a history of TBI and a CT diagnosis of cerebral contusion who had been treated during from August 2017 to July 2018 admitted in Coimbatore medical college hospital were accounted.

\section{Inclusion criteria :}

A cerebral contusion as the main post-traumatic intracranial lesion.

1. Cerebral contusion with haemorrhagic volume greater than $1 \mathrm{ml}$, as also reported by Chang et al. ${ }^{4}$

2. At least $3 \mathrm{CT}$ scans acquired during hospitalisation

3. complete and available clinical data with particular attention to any alterations

4. in neurological examination findings during the first hours after trauma; and

5. hospitalization on the $1^{\text {st }}$ day of TBI.

\section{Exclusion criteria :}

1. Cerebral contusion volume less than $1 \mathrm{ml}$, unsatisfactory and incomplete clinical report,

2. Lack of available follow-up CT scans

3. impossibility of assessing patients outcome after 6 months.

\section{Clinical data collection}

The following clinical data were collected and analysed for all patients:

1. age

2. $\operatorname{sex}$

3. mechanism of injury,

4. results of first GCS evaluation, 
5. history of concurrent conditions (hypertension and/or cardiopathy and/or diabetes), - treatment with an anticoagulant, onset of neurological deterioration during the first 12 hours after trauma, and neurosurgical intervention.

6. Patients were classified as neurologically deteriorating if the GCS score decreased by at least 2 points or if onset of pupillary abnormalities (as defined by Morris et al. ${ }^{21}$ ) was registered. The mechanism of injury was classified as either high velocity trauma or low- velocity trauma. ${ }^{30}$

\section{Radiological Assessment}

For each patient, we collected the first 3 CT scans, including the one taken at the time of hospital admission.

The CT images were read by a radiologist, who was mostly blinded as to the time

of the scan. Other radiological data collected and analysed

1. included the number of cerebral contusions \& its location,

2. hematoma volume \& oedema volume,

3. the presence of midline shift $(>5 \mathrm{~mm})$,

4. the presence of basal cistern effacement,

5. the presence of other posttraumatic intracranial lesions (subarachnoid haemorrhage, subdural hematoma, extradural hematoma, intraventricular haemorrhage, cranial fracture), and the number of intracranial lesions identified in association with the cerebral contusion.

The location of the cerebral contusion was distinguished regionally as frontal, temporal, parietal, occipital, posterior fossa (cerebellum or brainstem), or basal nucleus.

Hematoma volume was calculated by using the following formula: volume $=(\mathrm{ABC}) / 2(\mathrm{~cm} 3) .{ }^{10}$ For patients with more than 1 cerebral contusion, the volume of each contusion was calculated and then added to obtain the total volume of contusion. For most patients, the oedema component had a hypodense circumferential, not regular aspect. According to the attending radiologists, we registered 2 measurements: one including only the hyperdense (haemorrhagic) component and the other including the hypodense (pericontusion oedema) and hyperdense a (haemorrhagic) components of the lesion. By subtracting the first measurement from the second, we obtained a volume that was considered a reliable estimate of the hypodense component constituted by oedematous tissue in the first few hours after trauma. ${ }^{16}$ The midline shift was measured and the cases were divided according to a midline shift of more or less than $5 \mathrm{~mm}$. The status of basal cisterns was categorized as normal versus abnormal (compressed or absent).

On the second and third follow up CT scans, we assessed the following specific parameters:

1. percentage increase of hematoma size.

2. expansion of the oedema.

3. new onset or an increase of at least $2 \mathrm{~mm}$ in the midline shift.

4. worsening of the status of the basal cisterns.

5. expansion of at least one other posttraumatic intracranial lesion.

Evolution of hematoma size was defined as significant if enlargement of $30 \%$ of the original size was noted on CT scans, according to a recently published study ${ }^{1,2}$. Before choosing this expansion cut-off, we searched the literature for a recognized cut-off. We identified a cut-off of $30 \%$ volume increase in accordance with the more recent articles published on this issue, which considered increases of $25 \%, 30 \%$, and $33 \% .^{1,15,22,}$ The percentage increase of hematoma size was also inserted into the database as a linear variable. Unlike haemorrhage, a cut-off value for expansion of the oedema component of a contusion has not been established in the medical literature. In agreement with the previously defined cutoff, ${ }^{1,2}$ an increase of more than $30 \%$ of edema volume was considered significant. A worsening in the status of the basal cisterns was registered if a normal parameter became abnormal (compressed or absent cisterns). Expansion of other posttraumatic intracranial lesions was evaluated by the attending radiologist; all patients were stratified into 2 categories: 1) those with stable lesions or 2) those with an increase of at least 1 intracranial lesion. 


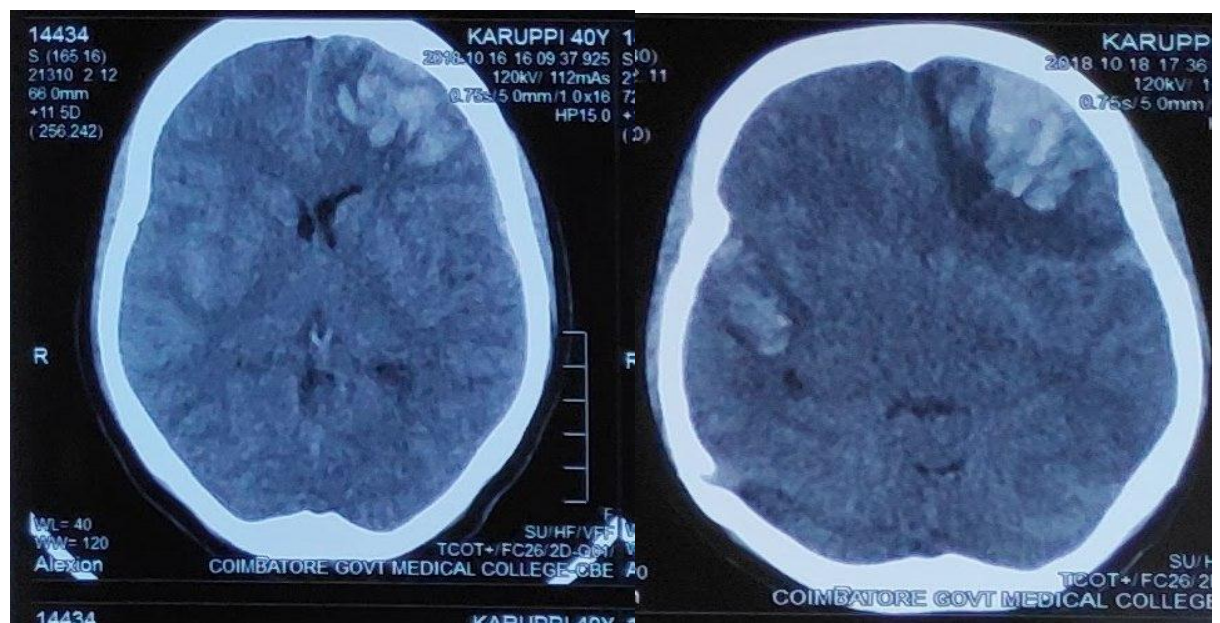

A) B)

Fig 1:-axial scans of ct brain( a \& b ) - initial scan obtained during admission showing left frontal haemorrhagic contusion with follow up scan after $24 \mathrm{hrs}$ showing increased oedema with midline shift.

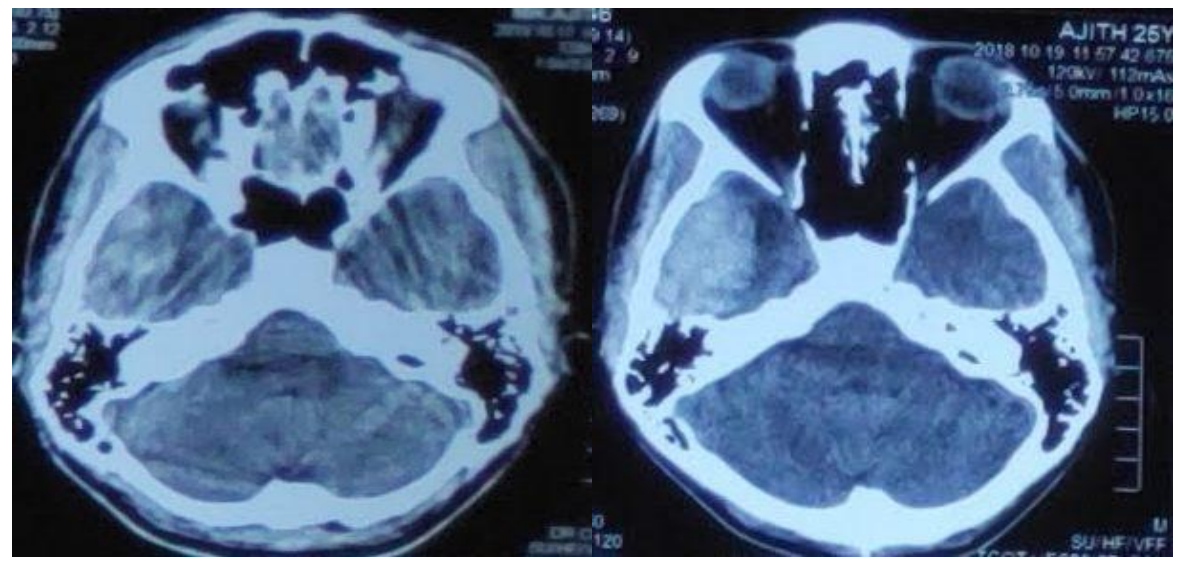

a) b)

Fig 2:-Axial scans of CT brain( a \& b ) - initial scan obtained during admission showing right temporal small haemorrhagic contusion with follow up scan after 6hrs showing increased contusion with midline shift.

\section{Statistical Analyses:-}

Prognostic factors were assessed by means of binary logistic regression models as follows: 1) univariate $\mathrm{p}$ value was calculated by using a logistic regression with single variables as predictors; and 2) multivariate p value was calculated by using an adjusted logistic regression model, including all predictors with a p value of at least 0.2 in the univariate model.

Furthermore, multi collinearity was excluded by performing a correlation matrix analysis (Pearson and Spearman correlation tests), considering the most clinically significant prognostic factor when the coefficient of determination (R2) is greater than 0.5. Residual output was also assessed to check residual values above or below 5 SDs, a cut-off based on the sample size of our patient group. For assessment of the diagnostic power of a given prognostic factor, a receiver operating characteristic (ROC) curve was used to calculate the area under the curve with $95 \%$ CIs and the cut-off value (for example, the flex point of the curve, where the sum of sensitivity and specificity wasn't the maximum). 
RESULTS

Table 1:-Epidemiological data description

\begin{tabular}{|c|c|}
\hline Varaiable & Total no. of Pts(\%) \\
\hline $\begin{aligned} & \text { 1. Sex } \\
-\quad & \text { Male } \\
- & \text { Female }\end{aligned}$ & $\begin{array}{r}128(72.7) \\
48(27.3)\end{array}$ \\
\hline $\begin{array}{ll} & \text { 2. Comorbidities } \\
- & \text { Present } \\
- & \text { Absent }\end{array}$ & $\begin{array}{r}68(38.63) \\
108(61.36)\end{array}$ \\
\hline $\begin{array}{l}\text { 3. Anticoagulant therapy } \\
\text { - } \quad \text { Present } \\
-\quad \text { Absent } \\
\end{array}$ & $\begin{array}{c}165(93.75) \\
11(6.25) \\
\end{array}$ \\
\hline $\begin{array}{l}\text { 4. Mechanism of injury } \\
\text { - } \quad \text { High velocity } \\
-\quad \text { Low velocity }\end{array}$ & $\begin{array}{r}103(58.52) \\
73(41.48)\end{array}$ \\
\hline $\begin{array}{ll} & 5 . \quad \text { GCS score at admission } \\
-\quad 3-8 \\
-\quad 9-13 \\
-\quad 14-15\end{array}$ & $\begin{array}{l}50(28.4) \\
53(30.1) \\
73(41.4) \\
\end{array}$ \\
\hline 6. Surgical procedure & $45(25.5)$ \\
\hline
\end{tabular}

Table II:-Parameters measured on CT brain images taken at the time of admission

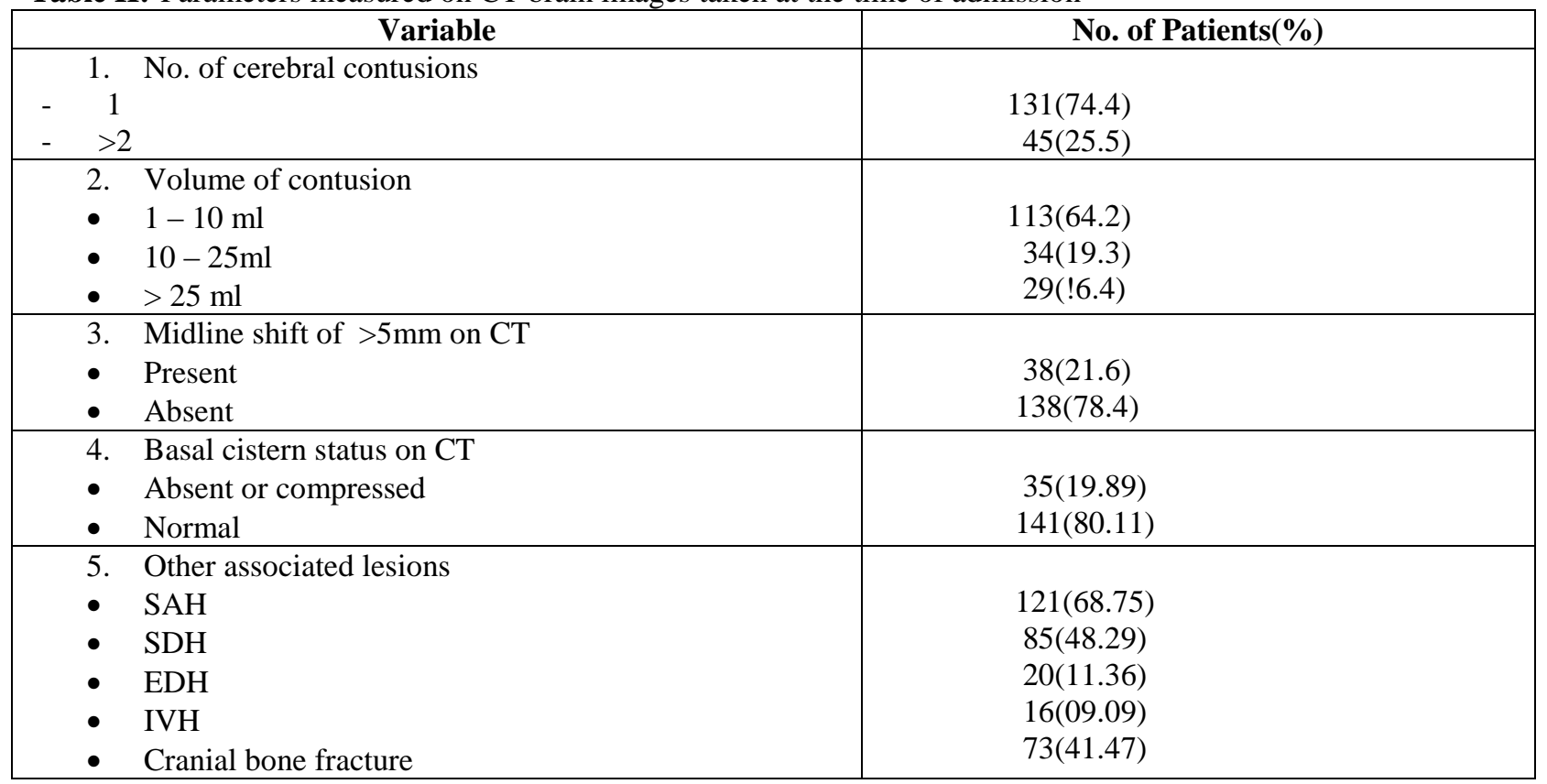

Table Iii:-Association between clinical and radiological parameters and need for surgery on $2^{\text {nd }}$ Scan

\begin{tabular}{|l|c|c|c|c|}
\hline \multicolumn{1}{|c|}{ Variable } & Surgery & No surgery & $\begin{array}{c}\text { Univariate p } \\
\text { value }\end{array}$ & $\begin{array}{c}\text { Multivariate p } \\
\text { value }\end{array}$ \\
\hline $1 . \quad$ GCS score at admission & & & & \\
$\bullet \quad 14-15$ & 10 & 70 & $<0.001$ & 0.03 \\
$\bullet \quad 9-13$ & 12 & 30 & 0.5 & 0.078 \\
$\bullet \quad 3-8$ & 38 & 16 & $<0.001$ & 0.019 \\
\hline
\end{tabular}




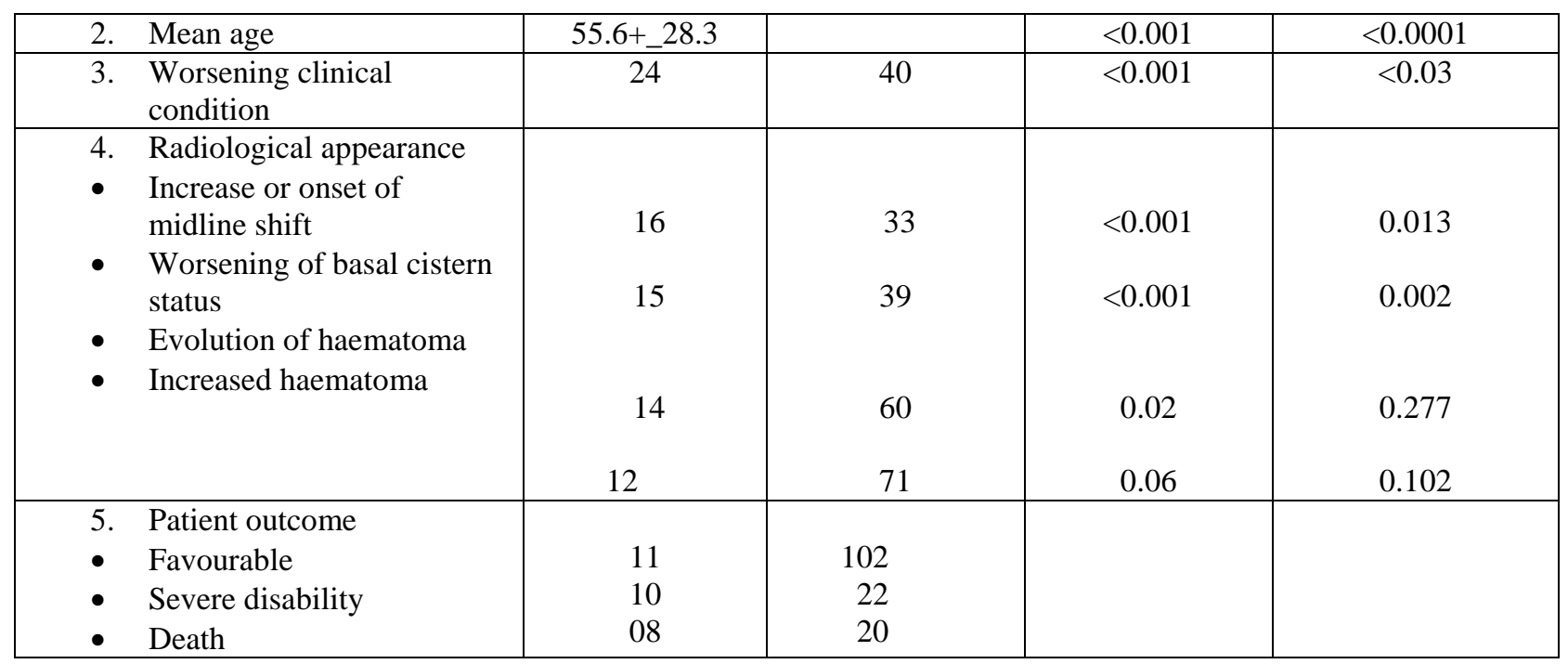

Table IV:-Clinical and radiological evolution

\begin{tabular}{|c|c|}
\hline Variable & No. Of cases (\%) \\
\hline $\begin{array}{ll}\text { 1. } & \text { Neurological deterioration } \\
\text { - } & \text { Absent } \\
\text { - } & \text { Present }\end{array}$ & $\begin{array}{r}116(65.9) \\
60(34.1)\end{array}$ \\
\hline $\begin{array}{ll}\text { 2. } & \text { Evolution of haematoma } \\
\text { - } & \text { Absent } \\
\text { - } & \text { Present }\end{array}$ & $\begin{array}{l}98(55.6) \\
78(44.4)\end{array}$ \\
\hline $\begin{array}{ll}\text { 3. } & \text { Increased oedema volume } \\
\text { - } & \text { Absent } \\
\text { - } & \text { Present }\end{array}$ & $\begin{array}{l}90(51.1) \\
86(48.9)\end{array}$ \\
\hline $\begin{array}{ll}\text { 4. } & \text { Midline shift on } 1^{\text {st }} \mathrm{CT} \text { film } \\
\text { - } & \text { Absent } \\
\text { - } & \text { Present }\end{array}$ & $\begin{array}{r}138(78.4) \\
38(22.6)\end{array}$ \\
\hline $\begin{array}{ll}\text { 5. } & \text { Appearance or increase of midline shift } \\
\text { - } & \text { Absent } \\
\text { - } & \text { Present }\end{array}$ & $\begin{array}{r}127(72.1) \\
49(27.9) \\
\end{array}$ \\
\hline $\begin{array}{ll}\text { 6. } & \text { Basal cistern status on admission CT } \\
\text { - } & \text { Absent or compressed } \\
\text { - } & \text { Normal }\end{array}$ & $\begin{array}{c}35(19.9) \\
141(80.1)\end{array}$ \\
\hline $\begin{array}{l}\text { 7. Onset or increase of basal cistern effacement } \\
\text { - Absent } \\
\text { - } \quad \text { Present }\end{array}$ & $\begin{array}{r}122(69.31) \\
54(30.69)\end{array}$ \\
\hline
\end{tabular}

Table V:-Predictors of favourable or unfavourable factors

\begin{tabular}{|c|c|c|c|c|}
\hline Predictor & $\begin{array}{c}\text { Univariate p } \\
\text { value }\end{array}$ & $\begin{array}{c}\text { Multivariate p } \\
\text { value }\end{array}$ & Exp ( B ) & 95\% CI as per Exp ( B ) \\
\hline Age & $<0.0001$ & 0.000 & 0.943 & $0.914-0.972$ \\
\hline Sex & 0.012 & 0.395 & 1.505 & $0.587-3.857$ \\
\hline Hypertension & 0.012 & 0.791 & 1.143 & $0.426-3.065$ \\
\hline Cardiopathy & $<0.0001$ & 0.863 & 0.902 & $0.280-2.905$ \\
\hline Diabetes & 0.013 & 0.395 & 1.765 & $0.476-6.537$ \\
\hline
\end{tabular}




\begin{tabular}{|l|l|l|l|l|}
\hline Anti coagulant therapy & 0.235 & 0.350 & 0.333 & $0.033-3.351$ \\
\hline INR at admission & $<0.0001$ & 0.323 & 0.448 & $0.091-2.203$ \\
\hline Mechanism of injury & $<0.0001$ & 0.434 & 0.062 & $0.235-1.862$ \\
\hline $\begin{array}{l}\text { GCS score at admission } \\
\bullet \quad-8\end{array}$ & & & & \\
$\bullet \quad<-13$ & $<0.0001$ & 0.000 & & \\
& $<0.0001$ & 0.000 & 0.034 & $0.010-0.113$ \\
\hline SAH & $<0.0001$ & 0.000 & 0.211 & $0.072-0.621$ \\
\hline SDH & 0.001 & 0.748 & 1.160 & $0.470-2.862$ \\
\hline EDH & 0.006 & 0.349 & 1.509 & $0.638-3.565$ \\
\hline Cranial fracture & 0.861 & 0.461 & 1.639 & $0.441-6.094$ \\
\hline Total haematoma volume & 0.363 & 0.136 & 0.518 & $0.219-1.229$ \\
\hline $\begin{array}{l}\text { Midline shift on admission } \\
\text { CT }\end{array}$ & $<0.0001$ & 0.366 & 0.969 & $0.906-1.037$ \\
\hline Clinical deterioration & $<0.0001$ & 0.243 & 0.396 & $0.086-1.819$ \\
\hline Surgery & 0.018 & 0.003 & 6.316 & $1.867-21.373$ \\
\hline Haematoma evolution & 0.002 & 0.419 & 0.616 & $0.910-1.995$ \\
\hline Oedema evolution & $<0.0001$ & 0.099 & 2.159 & $0.865-5.390$ \\
\hline $\begin{array}{l}\text { Midline shift on follow up } \\
\text { CT }\end{array}$ & $<0.0001$ & 0.520 & 0.713 & $0.254-2.000$ \\
\hline $\begin{array}{l}\text { Basal cistern status on } \\
\text { admission CT }\end{array}$ & $<0.0001$ & 0.000 & 10.668 & $3.268-34.827$ \\
\hline $\begin{array}{l}\text { Basal cistern status on } \\
\text { follow up CT }\end{array}$ & $<0.0001$ & 0.293 & 0.474 & $0.118-1.907$ \\
\hline $\begin{array}{l}\text { Increased haematoma } \\
\text { volume }\end{array}$ & $<0.0001$ & 0.663 & 1.914 & $0.694-5.280$ \\
\hline
\end{tabular}

Table VI:-Predictors of clinical deterioration

\begin{tabular}{|l|c|c|c|l|}
\hline \multicolumn{1}{|c|}{ Variable } & Univariate p value & $\begin{array}{c}\text { Multivariate p } \\
\text { value }\end{array}$ & Exp ( B & 95\% CI as per Exp ( B \\
\hline Midline shift on admission CT & 0.61 & 0.62 & 1.398 & $0.314-6.325$ \\
\hline Total haematoma volume & 0.0003 & 0.907 & 0.917 & $0.377-2.429$ \\
\hline Oedema volume evolution & $<0.0001$ & 0.703 & 0.836 & $0.326-2.249$ \\
\hline Midline shift on follow up CT & $<0.0001$ & 0.000 & 0.009 & $0.003-0.027$ \\
\hline $\begin{array}{l}\text { Basal cistern status on } \\
\text { admission CT }\end{array}$ & $<0.0001$ & 0.918 & 1.011 & $0.264-3.867$ \\
\hline $\begin{array}{l}\text { Basal cistern status on follow } \\
\text { up CT }\end{array}$ & $<0.0001$ & 0.000 & 0.045 & $0.020-0.145$ \\
\hline Haematoma evolution & $<0.0001$ & 0.157 & 1.031 & $0.978-1.130$ \\
\hline Increased haematoma volume & $<0.0001$ & 0.225 & 1.002 & $0.999-1.005$ \\
\hline
\end{tabular}

\section{Discussion:-}

The most frequent post traumatic intra-cerebral lesions are the Cerebral contusions. Our study included only those patients with brain contusion as main lesion and / or the prime reason for surgery, unlike the previous published studies. $^{2}$

In our study, older age is associated with a worst outcome. Age was found to be so prognostic that all the medical risk factors that are significant on univariate analysis are included by age on multivariate analysis. Glasgow coma scale scores have also been shown to be highly predictive of prognosis. ${ }^{6,20,22}$ Previous studies have shown the use of anti-platelet agents increases the risk for intracranial lesions ( contusions mainly ) after mild traumatic head injury. ${ }^{3}$ In multivariate analysis in our study, anti-platelet agents use clearly interacted with the age. 
Multivariate analyses revealed that none of the prognostic factors of admission CT scans ( haematoma volume, presence of associated lesions, midline shift and basal cistern status) were associated with clinical outcome. Admission CT scans ain't predict outcome since contusions by definition are lesions prone to evolve and and outcomes are related to the evolved CT scan as previously reported. We defined evolved haematoma as one that increases by more than $30 \% .^{2}$ Increase in volume of $25 \%{ }^{15}$ and $50 \%{ }^{6}$ have also been considered. Haemorrhagic progression of contusion can be might be detected even in patients with mild head injury. ${ }^{11}$

Severe cerebral contusion is often associated with non haemorrhagic mass effect that progress rapidly within $48 \mathrm{hrs}$ of trauma. Kawamata et al ${ }^{9}$ showed that cerebral contusion induces a rapid increase in tissue osmolality without contribution from inorganic ionic fluxes. Presence of subarachnoid haemorrhage ${ }^{6,15}$ presence of associated subdural haematoma ${ }^{2,15}$ and high volume of contusion at admission ${ }^{2,4}$ are the factors that predict the haematoma evolution according to literatures. Contusion of less than $10 \mathrm{ml}$ were never associated with haematoma evolution. ${ }^{1,2}$ We found a similar observation for single lesions in our study, confirming the relation between haematoma evolution and contusion size at admission. The limit of $25 \mathrm{ml}$ is used as clinical standard and guideline for surgical evacuation haematomas according to Marshall et al ${ }^{12}$ classifications for CT scans of TBI patients. This might be more sensitive and predictive prognostic index of outcome in our study. As per the multivariate analysis, the most reliable CT parameter related to outcome was the appearance or increase in midline shift. Our univariate analysis data demonstrated that clinical functional neurological worsening is associated with onset or increase of midline shift, haematoma evolution, increase in oedema and onset or increase of basal cistern effacement; only the onset or increase of oedema and basal cistern effacement were significant in our study. Alahmadi et al ${ }^{2}$ who reported that not all patients with haematoma progression subsequently showed clinical deterioration correlates our study. Narayan et al ${ }^{14}$ documented a link in a limited case series study between haematoma evolution and clinical deterioration. The correlation between clinical and radiological evolution remains controversial.

\section{Conclusion:-}

Clinical status (mild- moderate and severe TBI), radiological findings (single or multiple lesions, association with other hematomas, hematoma evolution), and outcomes are heterogeneous features among the patients with intracranial contusions. Progression of brain contusion on CT scan is a common finding, especially the larger contusions tend to progress more likely. Initial Poor GCS and larger contusion favours surgical intervention. The most reasonable indicator is a combination of clinical deterioration and increased midline shift/basal cistern compression.

\section{Bibilography:-}

1. Corrado Iaccarino, Paolo Schiavi, Edoarado Picetti et al MD: Patients with brain contusions: predictors of outcome and relationship between radiological and clinical evolution. J Neurosurg 120: 908 - 918, 2014

2. Alahmadi H, Vachhrajani S, Cusimano MD: The natural history of brain contusion: an analysis of radiological and clinical progression. Clinical article. J Neurosurg 112:1139-1145, 2010

3. Fabbri A, Sevadevi F, Marchesini G, Stein SC, Vandelli A : Predicting intracranial lesions by antiplatelet agents in subjects with mild head injury. J Nurosurg Psychiatry : 1275-1279, 2010

4. Chang EF, Meeker M, Holland MC: Acute traumatic intraparenchymal hemorrhage: risk factors for progression in the early post-injury period. Neurosurgery 58:647-656, 2006

5. Chesnut RM, Temkin N, Carney N, Dikmen S, Rondina C, VidettaW, et al: A trial of intracranial-pressure monitoring in traumatic brain injury. N Engl J Med 367:2471-2481, 2012

6. Chieregato A, Fainardi E, Morselli-Labate AM, Antonelli V, Compagnone C, Targa L, et al: Factors associated with neurological outcome and lesion progression in traumatic subarachnoid hemorrhage patients. Neurosurgery 56:671-680, 2005

7. Compagnone C, Murray GD, Teasdale GM, Maas AI, Esposito D, Princi P, et al: The management of patients with intradural post-traumatic mass lesions: a multicenter survey of current approaches to surgical management in 729 patients coordinated by the European Brain Injury Consortium. Neurosurgery

8. 57:1183-1192, 2005

9. Hukkelhoven CW, Steyerberg EW, Rampen AJ, Farace E, Habbema JD, Marshall LF, et al: Patient age and outcome following severe traumatic brain injury: an analysis of 5600 patients. J Neurosurg 99:666-673, 2003

10. Kawamata T, Mori T, Sato S, Katayama Y: Tissue hyperosmolalityand brain edema in cerebral contusion. Neurosurg Focus 22(5):E5, 2007 
11. Kothari RU, Brott T, Broderick JP, Barsan WG, Sauerbeck LR, Zuccarello M, et al: The ABCs of measuring intracerebral hemorrhage volumes. Stroke 27:1304-1305, 1996

12. Kurland D, Hong C, Aarabi B, Gerzanich V, Simard JM: Hemorrhagicprogression of a contusion after traumatic brain injury: a review. J Neurotrauma 29:19-31, 2012

13. Marshall LF, Marshall SB, Klauber MR, van Berkum Clark M, Eisenberg HM, Jane JA, et al: A new classification of head injury based on computerized tomography. J Neurosurg 75 (1S):S14-S20, 1991

14. Morris GF, Juul N, Marshall SB, Benedict B, Marshall LF: Neurological deterioration as a potential alternative endpoint in human clinical trials of experimental pharmacological agents for treatment of severe traumatic brain injuries. Neurosurgery 43:1369-1374, 1998

15. Narayan RK, Maas AI, Servadei F, Skolnick BE, Tillinger MN, Marshall LF: Progression of traumatic intracerebral hemorrhage: a prospective observational study. J Neurotrauma 25: 629-639, 2008

16. Oertel M, Kelly DF, McArthur D, Boscardin WJ, Glenn TC, Lee JH, et al: Progressive hemorrhage after head trauma: predictors and consequences of the evolving injury. J Neurosurg 96:109-116, 2002

17. Peterson EC, Chesnut RM: Talk and die revisited: bifrontal contusions and late deterioration. J Trauma $71: 1588-1592,2011$

18. Servadei F, Nanni A, Nasi MT, Zappi D, Vergoni G, Giuliani G, et al: Evolving brain lesions in the first 12 hours after head injury: analysis of 37 comatose patients. Neurosurgery 37:899-907, 1995

19. Smith JS, Chang EF, Rosenthal G, Meeker M, von Koch C, Manley GT, et al: The role of early follow-up computed tomography imaging in the management of traumatic brain injury patients with intracranial hemorrhage. J Trauma 63:75-82,

20. 2007

21. Snoek A, Dekker M, Lagrand T, Epema A, van der Ploeg T, van den Brand JG: A clinical decision model identifies patients at risk for delayed diagnosed injuries after high-energy trauma. Eur J Emerg Med 20:167172,2013

22. Soloniuk D, Pitts LH, Lovely M, Bartkowski H: Traumatic intracerebralhematomas: timing of appearance and indications for operative removal. J Trauma 26:787-794, 1986

23. Tagliaferri F, Compagnone C, Korsic M, Servadei F, Kraus J: A systematic review of brain injury epidemiology in Europe. Acta Neurochir (Wien) 148:255-268, 2006

24. White CL, Griffith S, Caron JL: Early progression of traumatic cerebral contusions: characterization and risk factors. J Trauma 67:508-515, 2009

25. Wilson JT, Pettigrew LE, Teasdale GM: Structured interviews for the Glasgow Outcome Scale and the extended Glasgow Outcome Scale: guidelines for their use. J Neurotrauma 15: 573-585, 1998

26. Yadav YR, Basoor A, Jain G, Nelson A: Expanding traumatic intracerebral contusion/hematoma. Neurol India 54:377-381, 2006. 